Article

\title{
Treatment of a Mature Landfill Leachate: Comparison between Homogeneous and Heterogeneous Photo-Fenton with Different Pretreatments
}

\author{
Javier Tejera ${ }^{1}$, Ruben Miranda ${ }^{1}{ }^{[}$, Daphne Hermosilla ${ }^{2}$, Iñigo Urra ${ }^{1}$, Carlos Negro ${ }^{1}$ and \\ Ángeles Blanco 1,*D \\ 1 Department of Chemical Engineering and Materials, Facultad de Ciencias Químicas, Ciudad Universitaria \\ $\mathrm{s} / \mathrm{n}$, Complutense University of Madrid, 28040 Madrid, Spain \\ 2 School of Bioenergy, Agronomic, and Forestry Industry Engineering, Campus Duques de Soria, University of \\ Valladolid, 42005 Soria, Spain \\ * Correspondence: ablanco@ucm.es
}

Received: 15 July 2019; Accepted: 2 September 2019; Published: 5 September 2019

check for updates

\begin{abstract}
This study focuses on the treatment of a mature landfill leachate by coagulation and photo-Fenton at different conditions. Optimal coagulation is carried out with ferric chloride in acid conditions; and with alum in near-neutral conditions, to minimize the use of sulphuric acid for $\mathrm{pH}$ adjustment $(1 \mathrm{~g} / \mathrm{L}$ vs. $7.2 \mathrm{~g} / \mathrm{L})$, the generation of sludge and the increase of conductivity in the final effluent. In both cases, a similar chemical oxygen demand (COD) removal is obtained, higher than $65 \%$, which is high enough for a subsequent photo-Fenton treatment. However, the removal of absorbance at $254 \mathrm{~nm}$ (UV-254) was significantly higher with ferric chloride ( $83 \%$ vs. $55 \%$ ), due to the important removal of humic acids at acid $\mathrm{pH}$. The best results for coagulation are $2 \mathrm{~g} / \mathrm{L}$ ferric chloride at initial $\mathrm{pH}=5$ and $5 \mathrm{~g} / \mathrm{L}$ alum at initial $\mathrm{pH}=7$. After coagulation with ferric chloride, the final $\mathrm{pH}$ (2.8) is adequate for a homogeneous photo-Fenton using the remaining dissolved iron $(250 \mathrm{mg} / \mathrm{L})$. At these conditions, using a ratio $\mathrm{H}_{2} \mathrm{O}_{2} / \mathrm{COD}=2.125$ and 30 min contact time, the biodegradability increased from 0.03 to 0.51 . On the other hand, the neutral $\mathrm{pH}$ after alum coagulation (6.7) allows the use of zero valent iron (ZVI) heterogeneous photo-Fenton. In this case, a final biodegradability of 0.32 was obtained, after $150 \mathrm{~min}$, using the same $\mathrm{H}_{2} \mathrm{O}_{2} / \mathrm{COD}$ ratio. Both treatments achieved similar results, with a final COD, UV-254 and color removal greater than $90 \%$. However, the economic assessment shows that the approach of ferric chloride + homogeneous photo-Fenton is much cheaper $\left(6.4 € / \mathrm{m}^{3}\right.$ vs. $28.4 € / \mathrm{m}^{3}$ ). Although the discharge limits are not achieved with the proposed combination of treatments, the significant increase of the pre-treated leachate biodegradability allows achieving the discharge limits after a conventional biological treatment such as sequencing batch reactor, which would slightly increase the total treatment cost.
\end{abstract}

Keywords: landfill leachate treatment; coagulation; photo-Fenton; ZVI; biodegradability

\section{Introduction}

Municipal solid waste (MSW) generation is increasing due to population growth, the modification of lifestyles and increased industrialization all around the world. Even landfilling is the last waste-management option; this option is still necessary for the disposal of non-recyclable materials; it has been extensively used extensively in the past due to its simplicity and lower management cost [1-3]. Other management options such as energy valorization are more expensive and still produce $10-20 \%$ ash, which usually must be landfilled [4].

At present, a huge number of landfills exist worldwide. Due to the percolation of the rainfall through residues and the decomposition of organic matter, a high-strength wastewater named landfill 
leachate (LL) is generated. LL is produced during landfill operation but also decades after its complete closure, representing a high risk for the environment [5,6]. LL characteristics depends mainly on landfill age but also on climate conditions and the wastes landfilled $[7,8]$. Table 1 shows the main characteristics of LL according to the landfill age.

Table 1. Characteristics of landfill leachates according to landfill age [9-11].

\begin{tabular}{|c|c|c|c|}
\hline & \multicolumn{3}{|c|}{ Type of Leachate } \\
\hline & Young & Intermediate & Old \\
\hline Age (years) & $0-10$ & $10-20$ & $>20$ \\
\hline $\mathrm{pH}$ & $<6.5$ & $6.5-7.5$ & $>7.5$ \\
\hline $\mathrm{BOD}_{5} / \mathrm{COD}$ & $0.5-1.0$ & $0.1-0.5$ & $<0.1$ \\
\hline $\mathrm{BOD}_{5}\left(\mathrm{mgO}_{2} / \mathrm{L}\right)$ & $>4000$ & $1000-4000$ & $<400$ \\
\hline $\mathrm{COD}\left(\mathrm{mgO}_{2} / \mathrm{L}\right)$ & $>10,000$ & $4000-10,000$ & $<4000$ \\
\hline TOC $(\mathrm{mg} / \mathrm{L})$ & $>2500$ & $1000-2500$ & $<1000$ \\
\hline $\mathrm{N}-\mathrm{NH}_{3}(\mathrm{mg} / \mathrm{L})$ & $<400$ & - & $>400$ \\
\hline Heavy metals & Low-medium & Low & Low \\
\hline $\begin{array}{l}\text { Recommended treatment } \\
\text { Composition }\end{array}$ & $\begin{array}{l}\text { Biological } \\
\text { VFA }(80 \%)\end{array}$ & VFA $(5-30 \%), H A, F A$ & $\begin{array}{l}\text { Physico-chemical } \\
\text { HA and FA }(80 \%)\end{array}$ \\
\hline
\end{tabular}

Note: $\mathrm{BOD}_{5}$ : biochemical oxygen demand; COD: chemical oxygen demand; TOC: total organic carbon; VFA: volatile fatty acids; HA: humic acids; FA: fulvic acids.

The first treatment option for LL is always biological treatment, either anaerobic or aerobic, due to their simple operation and low cost [12], as for example constructed wetlands [13], aerated lagoons, rotating biological reactors, etc. [14]. However, this is only possible for young and intermediate LL. Mature LL have a very low biodegradability $\left(\mathrm{BOD}_{5} / \mathrm{COD}<0.1\right)$ to be treated efficiently by biological methods. Furthermore, the presence of recalcitrant organic compounds, high levels of salts, and heavy metals makes this option unfeasible. Therefore, mature LL must be treated by physical or chemical treatments such as coagulation/flocculation [15,16], chemical precipitation [17] or advanced oxidation processes (AOPs), either to obtain a final effluent which can be discharged into the environment, or to increase its biodegradability to be further treated in a subsequent conventional biological treatment.

Coagulation/flocculation is a cost-efficient option to remove organic substances and color from the LL. Different authors have obtained intermediate and high COD and color removals, depending on the coagulant used and the $\mathrm{pH}$ of the treatment. While in the best cases it is possible to obtain COD and color removals in the $60-70 \%$ range, the biodegradability is not affected. The most widely used coagulants are ferric chloride and alum due to their low cost and good efficiency [18], ferric chloride usually obtaining better results than alum at similar pHs and dosages. For example, Amor et al. (2015) obtained $63 \% \mathrm{COD}$ and $80 \%$ color removal by coagulation at $\mathrm{pH} 6$ with $4 \mathrm{~g} / \mathrm{L}$ of $\mathrm{FeCl}_{3} \cdot 6 \mathrm{H}_{2} \mathrm{O}$ [19], while Silva et al. (2004) reported $23 \%$ and $70 \%$ for COD and color removal, respectively, when coagulating with alum $(\mathrm{pH}=3-4)$ [20].

Coagulation is an excellent pre-treatment for AOPs, which can efficiently remove bio-recalcitrant matter and improving the biodegradability of the LL [21]. The most widely used AOPs are ozonation [22,23], photocatalysis [24,25], electro-oxidation [26,27], and Fenton processes including conventional Fenton, electro-Fenton, photo-Fenton, heterogeneous Fenton, etc. [28]. Fenton treatments are preferred for high organic loaded effluents because of the lower chemical dosages (lower cost) and better efficiency in terms of COD removal [29].

The conventional homogeneous Fenton process uses $\mathrm{Fe}^{2+}$, normally added as iron sulfate [29-31], as catalyst to decompose hydrogen peroxide into high reactive hydroxyl radicals, which is a strong oxidant for organic matter (Equation (1)).

$$
\mathrm{Fe}^{2+}+\mathrm{H}_{2} \mathrm{O}_{2} \rightarrow \mathrm{Fe}^{3+}+\mathrm{HO} \cdot+\mathrm{HO}^{-}
$$


Different authors have reported a high COD removal (60-80\%) treating LL by conventional Fenton at $\mathrm{H}_{2} \mathrm{O}_{2} / \mathrm{COD}$ ratio varying from 0.531 up to 6.808 and acid $\mathrm{pH}(\mathrm{pH} \approx 2.8)$ [29-31].

In photo-Fenton processes, ultraviolet (UV) radiation enhances the efficiency and the kinetics of the process $[19,32,33]$. UV radiation causes the reduction from $\mathrm{Fe}^{3+}$ to $\mathrm{Fe}^{2+}$, as shown in Equation (2), allowing using low iron concentration as it can be reused several times in a cyclic process, with the advantage of lower sludge production during neutralization and precipitation of the dissolved iron after the treatment. If LL is pre-coagulated with an iron salt, the residual iron can act as catalyst.

$$
\mathrm{Fe}^{3+}+\mathrm{hv} \rightarrow \mathrm{Fe}^{2+}
$$

However, the use of iron salts has the problem of increasing the conductivity of the treated waters [34]. An option to avoid the use of iron salts is in situ generation by using iron shavings in acidic media [35], however, the kinetic is very slow while still existing the problem of iron sludge generation.

To avoid those problems, there is a growing interest in using ZVI as the iron source in Fenton processes. In this case, the reaction occurs in heterogeneous phase [36]. The formation of $\mathrm{Fe}^{2+}$ and the reduction of $\mathrm{Fe}^{3+}$ occur in the surface of ZVI following Equation (3).

$$
2 \mathrm{Fe}^{3+}+\mathrm{Fe}^{0} \rightarrow 3 \mathrm{Fe}^{2+}
$$

Furthermore, the use of ZVI allows working at neutral $\mathrm{pH}$ and can be reused several cycles $[34,37]$.

Due to the high consumption of energy and chemicals for the direct use of AOPs without any pretreatment, the combination of coagulation/flocculation and AOPs seems to be the best option to treat the mature landfill leachates [19,38]. Amor et al. (2015) [19] reported an increase in TOC removal from $54 \%$ with a single solar-photo-Fenton up to $75 \%$ using a coagulation pre-treatment with $2 \mathrm{~g} / \mathrm{L}$ of $\mathrm{FeCl}_{3}$ at $\mathrm{pH}=5$. Similarly, at $\mathrm{pH}=3$, Bogacki et al. (2019) [38] achieved a total TOC removal of $75 \%$ combining coagulation with ferric chloride $(1 \mathrm{~g} / \mathrm{L}$ at $\mathrm{pH}=6)$, and heterogeneous Fenton process $\left(\mathrm{Fe}^{0} / \mathrm{H}_{2} \mathrm{O}_{2}=1.4\right.$ ratio). However, a systematic comparison of coagulation with ferric chloride and alum as pretreatment for a photo-Fenton process has not been published yet. Furthermore, the potential viability of a treatment at neutral $\mathrm{pH}$ has not been fully explored.

Therefore, the novelty of this paper is that two treatment chains for a mature LL, based on coagulation and photo-Fenton processes in acid and neutral $\mathrm{pH}$, have been studied and compared. from a technical and economical point of view. The first approach combines coagulation with $\mathrm{FeCl}_{3}$ and photo-Fenton, using the remaining dissolved iron from coagulation $\left(\mathrm{Fe}^{3+}\right)$ as catalyst at acidic $\mathrm{pH}$. The second approach combines coagulation with alum and photo-Fenton with ZVI, as the iron source, at neutral conditions, which is a promise way to treat the LL at neutral $\mathrm{pH}$, expending less amount of reagents. This last approach explores the LL treatment at near-neutral $\mathrm{pH}$ to minimize the use of acid, the sludge generation and the increase of conductivity in the final effluent. Both treatments trains are compared in terms of efficiency in the removal of contaminants and increase of biodegradability.

\section{Materials and Methods}

\subsection{Landfill Leachate (LL)}

LL was collected from the MSW landfill located in Golmayo (Soria, Spain), which has been operating since 1997. The main characteristics are shown in Table 2. It is observed that its low biodegradability $\left(\mathrm{BOD}_{5} / \mathrm{COD}=0.03\right), \mathrm{pH}=8.2$ and $\mathrm{COD}=4961 \mathrm{mg} \mathrm{O}_{2} / \mathrm{L}$, correspond to a typical mature LL $[9,39]$. 
Table 2. Characteristics of the landfill leachate used in this study.

\begin{tabular}{|c|c|c|c|}
\hline $\begin{array}{c}\text { Parameters } \\
\text { (Raw Leachate) }\end{array}$ & Value & $\begin{array}{c}\text { Parameters } \\
\text { (Dissolved Fraction) }\end{array}$ & Values \\
\hline $\mathrm{pH}$ & $8.2 \pm 0.1$ & Chlorides $\left(\mathrm{mg} \mathrm{L}^{-1}\right)$ & $3000 \pm 137$ \\
\hline Conductivity $\left(\mathrm{mS} \mathrm{cm}^{-1}\right)$ & $17.3 \pm 0.1$ & Sulphates $\left(\mathrm{mg} \mathrm{L}^{-1}\right)$ & $125 \pm 23$ \\
\hline UV-254 $\left(\mathrm{cm}^{-1}\right)$ & $27.5 \pm 0.1$ & Aluminium $\left(\mathrm{mg} \mathrm{L}^{-1}\right)$ & $5.50 \pm 0.03$ \\
\hline Color (mg Pt L $\left.{ }^{-1}\right)$ & $17,300 \pm 200$ & Iron $\left(\mathrm{mg} \mathrm{L}^{-1}\right)$ & $8.50 \pm 0.015$ \\
\hline $\mathrm{COD}\left(\mathrm{mg} \mathrm{O}_{2} \mathrm{~L}^{-1}\right)$ & $4961 \pm 496$ & Chromium $\left(\mathrm{mg} \mathrm{L}^{-1}\right)$ & $1.90 \pm 0.05$ \\
\hline $\mathrm{BOD}_{5}\left(\mathrm{mg} \mathrm{O}_{2} \mathrm{~L}^{-1}\right)$ & $150 \pm 50$ & Sodium $\left(\mathrm{mg} \mathrm{L}^{-1}\right)$ & $2152 \pm 215$ \\
\hline $\mathrm{BOD}_{5} / \mathrm{COD}$ & $0.03 \pm 0.01$ & Potassium (mg L $\left.{ }^{-1}\right)$ & $1219 \pm 122$ \\
\hline $\mathrm{TOC}\left(\mathrm{mg} \mathrm{C} \mathrm{L}^{-1}\right)$ & $2000 \pm 100$ & Magnesium $\left(\mathrm{mg} \mathrm{L}^{-1}\right)$ & $98 \pm 6$ \\
\hline $\mathrm{TS}\left(\mathrm{mg} \mathrm{L}^{-1}\right)$ & $21,290 \pm 1030$ & Calcium $\left(\mathrm{mg} \mathrm{L}^{-1}\right)$ & $134 \pm 4$ \\
\hline $\mathrm{TSS}\left(\mathrm{mg} \mathrm{L}^{-1}\right)$ & $1370 \pm 20$ & Silicon $\left(\mathrm{mg} \mathrm{L}^{-1}\right)$ & $15 \pm 1$ \\
\hline $\operatorname{TDS}\left(\mathrm{mg} \mathrm{L}^{-1}\right)$ & $18,970 \pm 230$ & Zinc $\left(\mathrm{mg} \mathrm{L}^{-1}\right)$ & $0.61 \pm 0.06$ \\
\hline Alkalinity $\left(\mathrm{mg} \mathrm{CaCO}_{3} \mathrm{~L}^{-1}\right)$ & $13,244 \pm 100$ & Nickel $\left(\mathrm{mg} \mathrm{L}^{-1}\right)$ & $0.26 \pm 0.03$ \\
\hline $\mathrm{TN}_{\mathrm{b}}\left(\mathrm{mg} \mathrm{N} \mathrm{L}^{-1}\right)$ & $1600 \pm 10$ & Copper $\left(\mathrm{mg} \mathrm{L}^{-1}\right)$ & $0.030 \pm 0.003$ \\
\hline $\mathrm{TP}\left(\mathrm{mg} \mathrm{P} \mathrm{L}^{-1}\right)$ & $10 \pm 2$ & & \\
\hline
\end{tabular}

Note: TS: total solids; TSS: total suspended solids; TDS: total dissolved solids; $\mathrm{TN}_{\mathrm{b}}$ : total nitrogen bound; TP: total phosphorus.

\subsection{Chemicals}

Aluminum sulphate, $\mathrm{Al}_{2}\left(\mathrm{SO}_{4}\right)_{3} \cdot 18 \mathrm{H}_{2} \mathrm{O}(99.5 \%)$, and ferric chloride, $\mathrm{FeCl}_{3} \cdot 6 \mathrm{H}_{2} \mathrm{O}(99 \%)$, were used as $50 \mathrm{wt} \%$ solutions, prepared from the reagents obtained from Sigma-Aldrich using distilled water. An anionic flocculant of high molecular weight from Kemira was used at $0.025 \mathrm{wt} \%$ solution in distilled water. Sulphuric acid, $\mathrm{H}_{2} \mathrm{SO}_{4}(96-98 \%)$, also from Sigma-Aldrich, was used for $\mathrm{pH}$ adjustment, as received.

For the photo-Fenton process, hydrogen peroxide (35\% wt $\%$ ) was purchased from Sigma-Aldrich (Highland, IL, USA) and $\mathrm{Fe}^{0}$ microspheres ( $>98.3 \% \mathrm{Fe} ;<1 \% \mathrm{C} ;<1 \% \mathrm{~N} ;<0.7 \% \mathrm{O}$ ) with $1 \mu \mathrm{m}$ of particle size and $800 \mathrm{~m}^{2} \mathrm{~kg}^{-1}$ of surface area were supplied by BASF (ZVI Microspheres 800, Ludwigshafen, Germany).

\subsection{Coagulation}

Ferric chloride and alum were studied in a jar-test at five different initial $\mathrm{pHs}$ (from the initial $\mathrm{pH}$ of the landfill, $\mathrm{pH}=8.2$, to $\mathrm{pH}=4$ ) at dosages varying from 0 to $30 \mathrm{~g} / \mathrm{L}$, to determine the optimal concentrations for $\mathrm{COD}$ and color removal; those $\mathrm{pHs}$ were used because these coagulants work better in acidic media [40]. Tests were carried out in $500 \mathrm{~mL}$ beakers filled with $250 \mathrm{~mL}$ of sample in a flocculation tester applying fast mixing during $5 \mathrm{~min}(150 \mathrm{rpm})$ for coagulation, followed by slow mixing during $30 \mathrm{~min}$ (50 rpm) for flocculation, as typical times and velocities for coagulation/flocculation. Finally, the sample settled for $60 \mathrm{~min}$ and the clarified was analysed to determine the efficiency in the removal of contaminants.

\subsection{Photo-Fenton Process}

The photo-Fenton process was carried out using a high-pressure mercury immersion lamp of $450 \mathrm{~W}$ from ACE-Glass (Model 7825-30, Vineland, NJ, USA) inserted in a quartz glass cooled jacket, vertically positioned as described before $[9,34]$. Figure 1 shows a schematic diagram of the experimental setup. A total photon flux in the reactor of $1.1 \times 10^{20}$ photon/s was calculated according with [41] and the addressed values and methodology reported in [21]. Radiometry analyses were made using an UV radiometer model RM-21 (UV-Elektronik, Ettlingen, Germany). 1.75 L of coagulated leachate was stirred mechanically at $250 \mathrm{rpm}$. Then, iron microspheres (in heterogeneous Fenton process tests) were also added at different molar ratio of $\left[\mathrm{H}_{2} \mathrm{O}_{2}\right] /\left[\mathrm{Fe}^{0}\right]$, while no additional iron source was used for Fenton-like reaction in homogeneous phase. Afterwards, the appropriate amount of $\mathrm{H}_{2} \mathrm{O}_{2}$, 
depending on the ratio $\left[\mathrm{H}_{2} \mathrm{O}_{2}\right]_{0} /[\mathrm{COD}]_{0}$ used $(2.125,1.062,0.531)$, was added, maintaining constant the molar ratio $\mathrm{H}_{2} \mathrm{O}_{2} / \mathrm{Fe}=50$ for heterogeneous Fenton and the concentration of remaining dissolved iron after coagulation for the homogeneous Fenton. Keeping constant the remaining iron concentration implies $\left[\mathrm{H}_{2} \mathrm{O}_{2}\right] /\left[\mathrm{Fe}^{3+}\right]$ ratios of $5.55,11$ and 22 for $\left[\mathrm{H}_{2} \mathrm{O}_{2}\right]_{0} /[\mathrm{COD}]_{0}=2.125,1.063$ and 0.531 , respectively. Samples were taken at selected time intervals to analyse the removal of contaminants and the $\mathrm{H}_{2} \mathrm{O}_{2}$ consumption during the tests. Experiments were carried out by triplicate, obtaining a standard deviation in the results lower than 10\%. All the tests were performed at ambient temperature (approx. $\left.20^{\circ} \mathrm{C}\right)$.

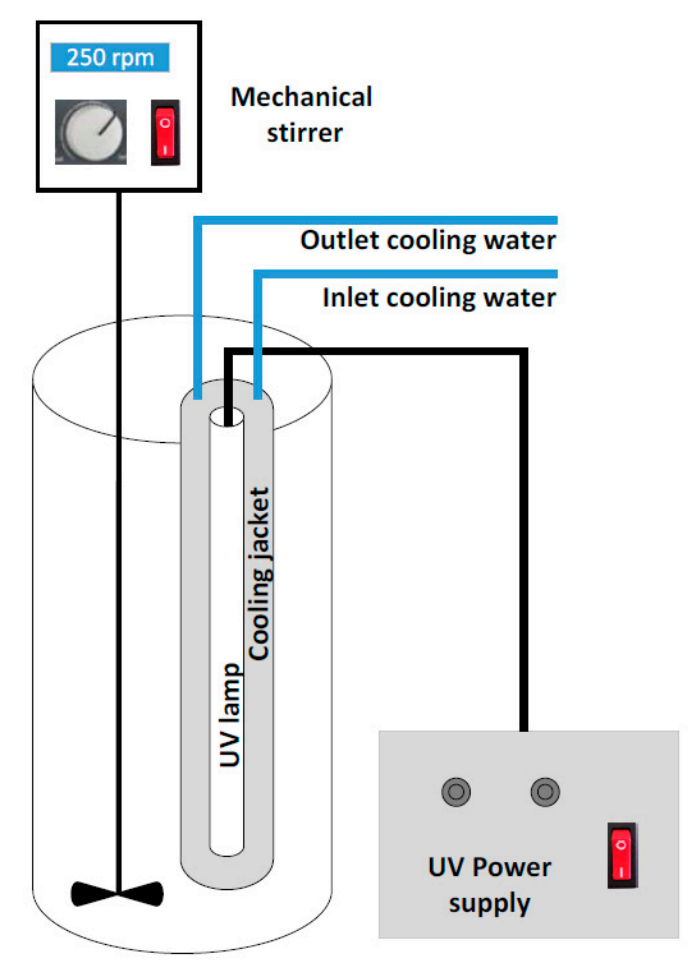

Figure 1. Photo-Fenton set-up.

\subsection{Analytical Determinations}

Conductivity and $\mathrm{pH}$ measurements were carried out using a $\mathrm{pH}$-meter Sension ${ }^{\mathrm{TM}}+\mathrm{MM} 374$ (Hach, Loveland, CO, USA) equipped with $\mathrm{pH}$ and conductivity probes following the standard methods for the examination of water and wastewaters (method 2510 and 2310, respectively) [42]. BOD (method 5210B) and total alkalinity (method 2320B) analyses were made according to standard methods [42]. COD, sulphates and chlorides were measured using Nanocolor ${ }^{\circledR}$ test methods (Macherey-Nagel $\mathrm{GmbH}$, Düren, Germany) using an Aquamate UV-Vis spectrophotometer (Thermo Fisher Scientific, Waltham, MA, USA) for the measurements. Turbidity was measured with a LP 2000-11 turbidity meter (Hanna Instruments, Laval, QC, Canada) following Standard Methods (method 2130) [42]. UV-254 was measured with a Varian Cary 50 UV-Visible Spectrophotometer (Varian, Palo Alto, CA, USA) using $1 \mathrm{~cm}$ pathway quartz cuvettes according to Standard Method 5910 [42]. TOC (method 5310) and total nitrogen $\left(\mathrm{TN}_{\mathrm{b}}\right.$ ) (UNE-EN-ISO 11905-1:1998) were measured by the combustion-infrared method using a TOC/TN Analyser Multi N/C ${ }^{\circledR} 3100$ (Analytik Jena AG, Jena, Germany) with catalytic oxidation on cerium oxide at $850{ }^{\circ} \mathrm{C} . \mathrm{H}_{2} \mathrm{O}_{2}$ concentration was analysed by the titanium sulphate spectrophotometric method [34,35]. Dissolved iron, aluminium and calcium were measured by atomic absorption spectrometry (Standard Methods 3111B, 3111E) in a Varian SpectrAA 220 spectrophotometer (Varian, Palo Alto, CA, USA) [42]. 


\section{Results and Discussion}

\subsection{Coagulation: Effect of $\mathrm{pH}$ and Dosage of Coagulants.}

Independently of the coagulant tested, the maximum COD removals were obtained at the lowest initial pHs, as shown in Figure 2. This agrees with previous references $[18,19]$. Furthermore, the lower initial $\mathrm{pH}$, the lower dosage of the coagulant to achieve the maximum COD removal. It is important to take into account that the necessary acid concentration for decreasing the $\mathrm{pH}$ of the LL was very high due to its high alkalinity $(13,244 \mathrm{mg} / \mathrm{L} \mathrm{CaCO})$. Therefore, this $\mathrm{pH}$ adjustment implies an increase of conductivity and concentration of salts (sulphates, as sulphuric acid was used for $\mathrm{pH}$ adjustment) which can also retard the Fenton process [43] and may imply posterior management difficulties. To decrease the $\mathrm{pH}$ from its initial value $\mathrm{pH}=8.2$ to $\mathrm{pH}=7$ and $\mathrm{pH}=5$, the conductivity increased from $24.9 \mathrm{mS} / \mathrm{cm}$ to $25.5 \mathrm{mS} / \mathrm{cm}$ and $26.4 \mathrm{mS} / \mathrm{cm}$, requiring 1 and $7.2 \mathrm{~g} / \mathrm{L}$ of sulphuric acid, respectively. Thus, the decrease in $\mathrm{pH}$ should be maintained as low as possible to reduce the costs of the chemicals used in the treatment and to avoid these drawbacks.

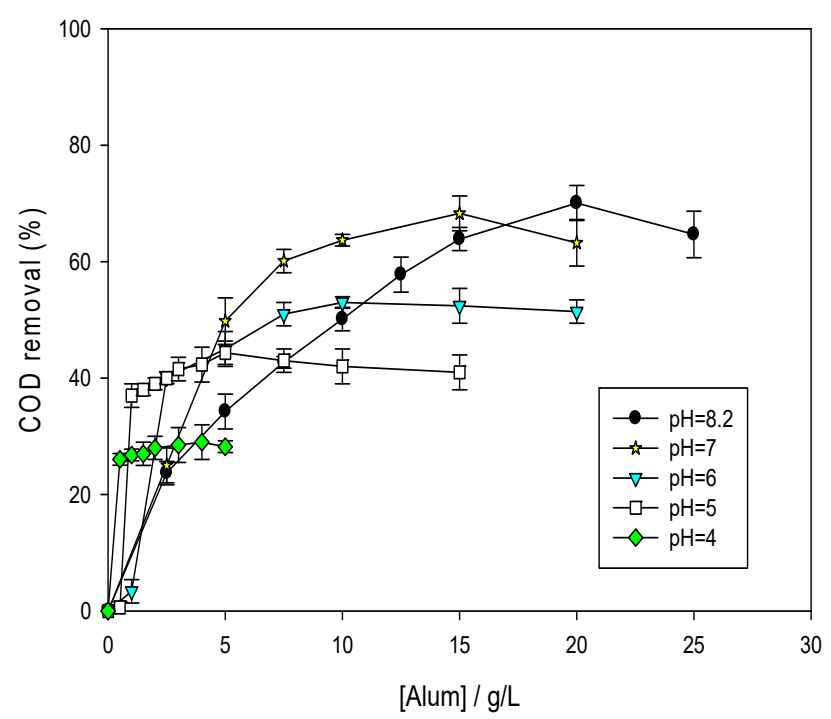

(a)

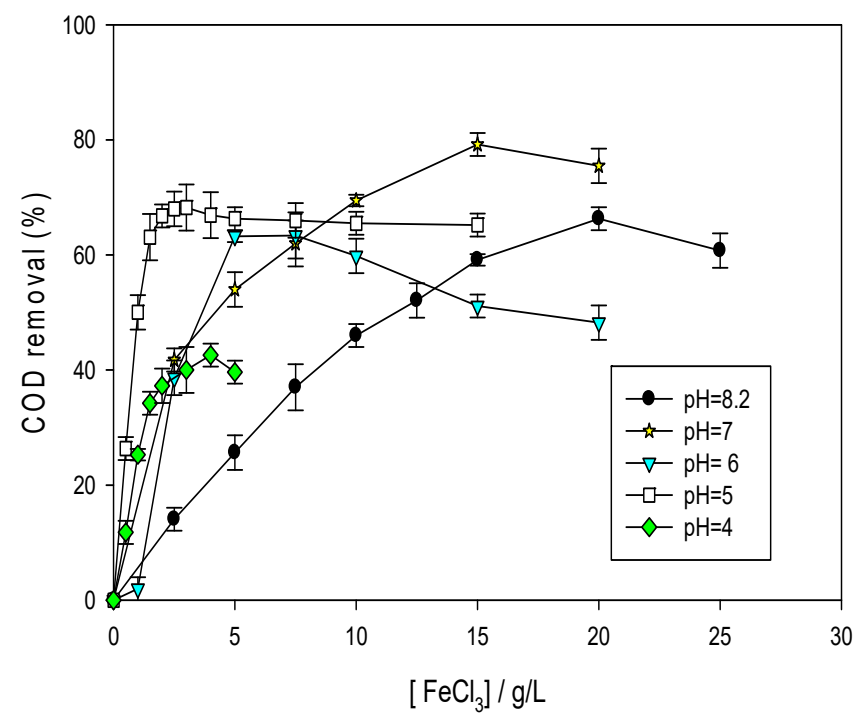

(b)

Figure 2. Removal of COD at initial pHs with (a) alum and (b) ferric chloride. 
Coagulation carried out with alum obtained the following maximum COD removals: $70 \%, 68 \%$, $53 \%, 44 \%$ and $29 \%$, obtained at $\mathrm{pH}=8.2(20 \mathrm{~g} / \mathrm{L}), 7(15 \mathrm{~g} / \mathrm{L}), 6(10 \mathrm{~g} / \mathrm{L}), 5(5 \mathrm{~g} / \mathrm{L})$ and $4(4 \mathrm{~g} / \mathrm{L})$, respectively. A decrease in the initial $\mathrm{pH}$ implies a decrease in the dosage of coagulant to achieve a high COD removal, thus the optimal $\mathrm{pH}$ for coagulation with alum would be $\mathrm{pH}=5-6$. It is also remarkable that even at $\mathrm{pH}=7(5 \mathrm{~g} / \mathrm{L}$ dosage), the COD removal obtained was $60 \%$, which is high enough for a photo-Fenton treatment. At these conditions, a lower dosage of alum is used while avoiding the addition of an important amount of sulphuric acid for $\mathrm{pH}$ adjustment. Moreover, remaining dissolved aluminium is a $20 \%$ lower after coagulation with $5 \mathrm{~g} / \mathrm{L}$ than at $15 \mathrm{~g} / \mathrm{L}$ of alum at $\mathrm{pH}=7$, with values of 47 and $59 \mathrm{mg} / \mathrm{L}$, respectively. The sulphates concentration in the leachate is also three times lower for $5 \mathrm{~g} / \mathrm{L}$ than for $15 \mathrm{~g} / \mathrm{L}$ (alum, $\mathrm{pH}=7$ ): $2.2 \mathrm{~g} / \mathrm{L}$ vs. $6.5 \mathrm{~g} / \mathrm{L}$.

The best efficiencies in COD removal obtained with ferric chloride were $66 \%, 79 \%, 63 \%, 66 \%$ and $43 \%$ at $\mathrm{pH}=8.2(20 \mathrm{~g} / \mathrm{L}), \mathrm{pH}=7(15 \mathrm{~g} / \mathrm{L}), \mathrm{pH}=6(5 \mathrm{~g} / \mathrm{L}), \mathrm{pH}=5(2 \mathrm{~g} / \mathrm{L})$ and $\mathrm{pH}=4(4 \mathrm{~g} / \mathrm{L})$, respectively, as shown in Figure 2. The lower $\mathrm{pH}$, the better COD removal per coagulant dosage, however, ferric chloride also presents a compromise among COD removal and the increase of conductivity, thus optimal $\mathrm{pH}$ is between $\mathrm{pH} 4$ and 5 . Optimal conditions were selected to initial $\mathrm{pH}=5$ and $2 \mathrm{~g} / \mathrm{L}$ of ferric chloride, which gives a final $\mathrm{pH}=2.8$ which fits very well with the optimum of a Fenton reaction [44]. Even when this is not the most acid $\mathrm{pH}$ tested, $7.2 \mathrm{~g} / \mathrm{L}$ of sulphuric acid are necessary for $\mathrm{pH}$ adjustment. On the other hand, the low ferric chloride dosage selected avoids higher concentrations of chlorides $(787 \mathrm{mg} / \mathrm{L}$ added) in the coagulated leachate, as chlorides are more detrimental than sulphates in terms of corrosion and conductivity of treated waters.

It is important to analyse the direct effect of $\mathrm{pH}$ on the removal of organics. If the $\mathrm{pH}$ decreases to around 4 , there is a large precipitation of humic acids (HA), which are very abundant in these leachates [45]. This effect partly explains why ferric chloride reach a greater COD removal with lower dosage of coagulant than alum. The final $\mathrm{pH}$ after coagulation with ferric chloride under optimal conditions is below 4, while for the optimal alum coagulation the final $\mathrm{pH}$ is 6.7. Thus, humic acid precipitation only occurs with $\mathrm{FeCl}_{3}$ coagulant. This direct relationship is novel and explains the lower efficiency of alum reported in the literature $[18,19]$. To further analyse this effect, $\mathrm{pH}$ decrease without coagulant addition was studied and it was observed that the lower $\mathrm{pH}$, the greater COD removal: $4 \%$ at $\mathrm{pH}=6,15 \%$ at $\mathrm{pH}=5$ and $25 \%$ at $\mathrm{pH}=4$. At $\mathrm{pHs}$ lower than 4 no additional COD removal was obtained.

Coagulation is a cheap pre-treatment to increase the efficiency of the photo-Fenton treatment and reduce the cost of the global treatment chain. In this study its effect was monitored based on color and UV-254, as shown in Table 3. If color and UV-254 are high, the UV radiation necessary to achieve a certain COD removal will be higher and thus the treatment costs, or in the worst case, the COD removal will be very limited even using high dosages of $\mathrm{H}_{2} \mathrm{O}_{2}$ and radiation times. Attending to these parameters, ferric chloride obtained better removal than alum $(97 \%$ vs. $87 \%)$ with final color values of 520 and $2250 \mathrm{mg} \mathrm{Pt} / \mathrm{L}$ after coagulation, respectively. The UV-254 indicates the presence of ultraviolet quenching substances (UVQS). When there are in high concentrations, they act as scavengers of UV, absorbing the radiation $[46,47]$. The UV-254 was reduced in a greater extent using ferric chloride: $83 \%$ vs. $55 \%$ obtaining final values of $12.4 \mathrm{vs} .4 .7 \mathrm{~cm}^{-1}$, respectively. This is explained due to the high humic acid removal obtained with the treatments carried out at $\mathrm{pH}$ lower than 4 [48]. These humic acids are responsible of a large amount of UV-254 quenching substances from mature leachates. As commented before, this complete precipitation only occurs in coagulation with ferric chloride (final $\mathrm{pH}=2.8$ ).

It is also important that during the coagulation at optimal conditions, independently of the coagulant used, $75 \%$ of total chromium, $90 \%$ of barium and nickel and a $20 \%$ of magnesium and manganese were also removed.

As expected, after coagulation there was no increase in the biodegradability, the ratio $\mathrm{BOD}_{5} / \mathrm{COD}$ of the raw water remained at around the same value of $0.03 \pm 0.02$.

In the literature, coagulation with ferric chloride is usually preferred to alum. Amor et al. (2015), for example, obtained $63 \%$ COD removal when using ferric chloride and only $31 \%$ when alum was 
employed [19]. However, in the present study, the efficiency in COD removal for both coagulants was very similar. This is an interesting novel approach due to its potential benefits since conductivity was significantly lower for alum than for ferric chloride ( $17 \mathrm{vs.} 22.5 \mathrm{mS} / \mathrm{cm})$, due to the coagulant dosage but also due to the lower dosage of sulphuric acid necessary for the optimal conditions $(1 \mathrm{~g} / \mathrm{L}$ vs. $7.2 \mathrm{~g} / \mathrm{L}$ ). The lower final conductivity is also important for a further biological post-treatment after increasing the biodegradability of the LL. The lower amount of sulphuric acid added means an economic advantage for alum, which is also cheaper than ferric chloride. Furthermore, the sludge generated by alum coagulation is significantly lower than by ferric chloride $[49,50]$. The final $\mathrm{pH}$ of after coagulation with alum $(5 \mathrm{~g} / \mathrm{L}$ at $\mathrm{pH}=7)$ is 6.7 , which also fits very well to the study of photo-Fenton treatment applying ZVI microspheres as an iron source, with the following additional advantages: it can be reused several times and avoids the need of a neutralization step after photo-Fenton process.

Table 3. Removal of contaminants at optimal conditions with alum and ferric chloride, which are the initial conditions for the subsequent Fenton treatment.

\begin{tabular}{|c|c|c|c|c|c|c|}
\hline & $\begin{array}{l}\text { Initial } \\
\mathrm{pH}\end{array}$ & $\begin{array}{c}\text { Final } \\
\text { pH }\end{array}$ & $\begin{array}{c}\text { Conductivity, } \\
\mathrm{mS} / \mathrm{cm}\end{array}$ & $\begin{array}{c}\mathrm{COD}, \mathrm{mg} \mathrm{O}_{2} / \mathrm{L} \\
\text { (\% Removal) }\end{array}$ & $\begin{array}{l}\text { Color, mg Pt/L } \\
\text { (\% Removal) }\end{array}$ & $\begin{array}{l}\text { UV-254, cm }{ }^{-1} \\
\text { (\% Removal) }\end{array}$ \\
\hline Raw leachate & 8.2 & - & $17.3 \pm 0.1$ & $4961 \pm 461$ & $17,300 \pm 100$ & $27.5 \pm 1$ \\
\hline $5 \mathrm{~g} / \mathrm{L}$ alum & 7.0 & 6.7 & $17.1 \pm 0.1$ & $1786 \pm 232(64 \%)$ & $2250 \pm 50(87 \%)$ & $12.4 \pm 1(55 \%)$ \\
\hline $2 \mathrm{~g} / \mathrm{L}$ ferric chloride & 5.0 & 2.8 & $22.5 \pm 0.1$ & $1588 \pm 226(68 \%)$ & $520 \pm 15(97 \%)$ & $4.7 \pm 1(83 \%)$ \\
\hline
\end{tabular}

These are the reasons to analyse subsequent Fenton treatment following two approaches: at acidic $\mathrm{pH}$ after coagulation with ferric chloride and at neutral $\mathrm{pH}$ after coagulation with alum.

A Fenton-like homogeneous process, without further addition of iron from other sources, is an interesting Fenton treatment when the levels of dissolved iron are already high enough in the waters. After the treatment with $2 \mathrm{~g} / \mathrm{L}$ of ferric chloride the dissolved iron was $250 \mathrm{mg} / \mathrm{L}$, this fact together with final $\mathrm{pH}$ after coagulation (2.8) allowed us to apply Fenton-like process without any other source of iron and $\mathrm{pH}$ adjustment [51].

The heterogeneous Fenton process, with the addition of ZVI as catalyst, is the best choice for landfill leachates coagulated with alum at neutral $\mathrm{pH}$. $\mathrm{pH}$ after coagulation is 6.7 , which fits very well to the optimal conditions for using the ZVI heterogeneous photo-Fenton process.

\subsection{Photo-Fenton Treatment}

The effect of the ratio $\mathrm{H}_{2} \mathrm{O}_{2} / \mathrm{COD}$ was carried out at stoichiometric, half of the stoichiometric and quarter of the stoichiometric ratios $(2.125,1.063$ and 0.531 , respectively) in both selected approaches. In those tests the iron concentration $250 \mathrm{mg} / \mathrm{L}$ in the case of coagulation pre-treatment with ferric chloride $\left(\left[\mathrm{H}_{2} \mathrm{O}_{2}\right] /\left[\mathrm{Fe}^{3+}\right]\right.$ ratios of $5.55,11$ and 22 for $\left[\mathrm{H}_{2} \mathrm{O}_{2}\right]_{0} /[\mathrm{COD}]_{0}=2.125,1.063$ and 0.531 , respectively) and $\mathrm{H}_{2} \mathrm{O}_{2} / \mathrm{Fe}=50$ for alum pre-coagulated leachate were keeping constant. In both cases, the $\mathrm{pH}$ was not adjusted after the coagulation treatment $(\mathrm{pH}=2.8$ for ferric chloride and $\mathrm{pH}=6.7$ for alum).

Figure 3 shows the main results of both approaches. The Fenton-like process after optimal coagulation treatment with $\mathrm{FeCl}_{3}$ achieved an important increase on biodegradability of the landfill leachate. At the stoichiometric $\mathrm{H}_{2} \mathrm{O}_{2} / \mathrm{COD}$ ratio (2.125), the ratio $\mathrm{BOD}_{5} / \mathrm{COD}$ increased to 0.51 with an extra COD removal of 70\% (total COD removal of 90\%). Amor et al. (2015) reported $89 \%$ COD removal during a similar process of treatment: coagulation with ferric chloride followed by solar photo-Fenton using $96 \mathrm{~h}$ [19]. The $\mathrm{BOD}_{5} / \mathrm{COD}$ increased to 0.32 at $\mathrm{H}_{2} \mathrm{O}_{2} / \mathrm{COD}=1.063$ with a COD removal of $48 \%$, but half UV irradiation time ( $15 \mathrm{~min}$ vs. $30 \mathrm{~min}$ ) being necessary. For the lowest ratio $\mathrm{H}_{2} \mathrm{O}_{2} / \mathrm{COD}$, the biodegradability increased to 0.25 with an additional $24 \%$ COD removal. The final COD for the two highest ratios $\mathrm{H}_{2} \mathrm{O}_{2} / \mathrm{COD}$ was below $1000 \mathrm{mg} \mathrm{O} 2 / \mathrm{L}$ (476 and $826 \mathrm{mg} \mathrm{O}_{2} / \mathrm{L}$ for 2.125 and 1.063, respectively). The biodegradability obtained at the two highest $\mathrm{H}_{2} \mathrm{O}_{2} / \mathrm{COD}$ ratios are high enough for the wastewater to be post-treated in a conventional biological reactor. The main difference between them is the treatment cost: the ratio $\mathrm{H}_{2} \mathrm{O}_{2} / \mathrm{COD}=1.063$ needs half $\mathrm{H}_{2} \mathrm{O}_{2}$ dosage $(1.69 \mathrm{~g} / \mathrm{L})$ and half 
of the irradiation time $(15 \mathrm{~min})$ than the $\mathrm{H}_{2} \mathrm{O}_{2} / \mathrm{COD}=2.125$ ratio. UV-254 removal also increased at greater $\mathrm{H}_{2} \mathrm{O}_{2} / \mathrm{COD}$ ratios, from $57 \%$ to $85 \%$ and $93 \%$, respectively, in agreement with the literature [46]. Other parameters such as $\mathrm{pH}$, conductivity or metal concentration were maintained in a very similar level after the treatment.

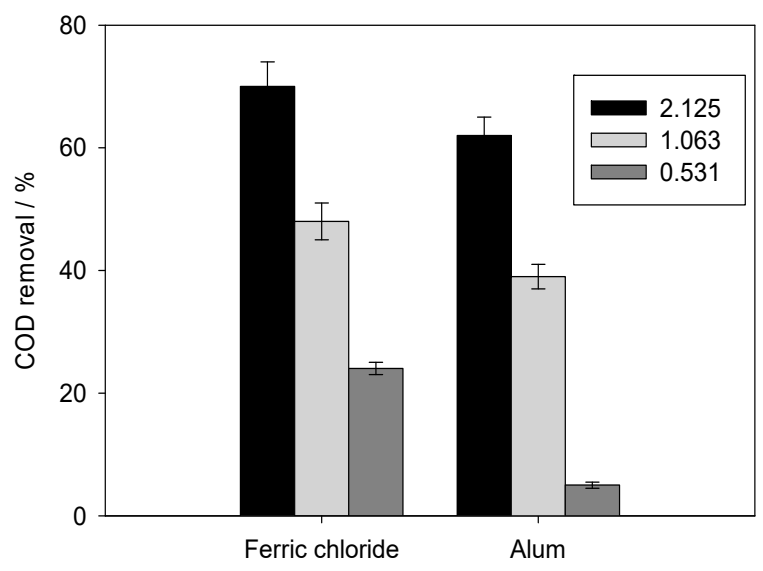

(a)

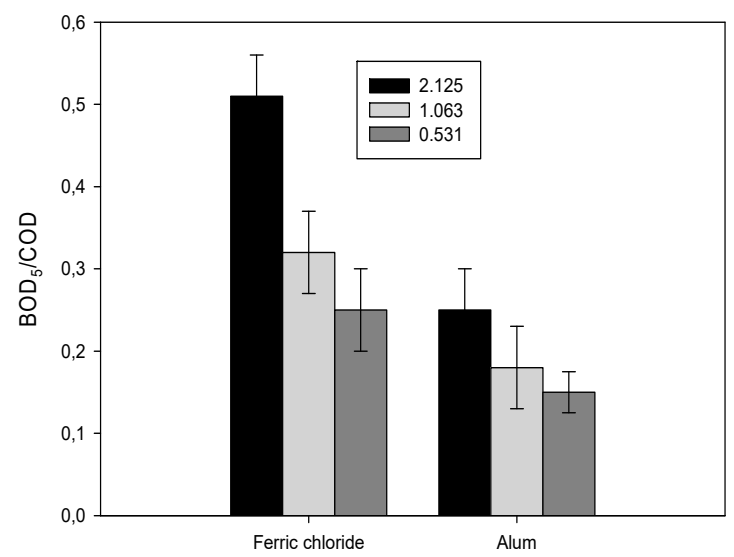

(b)

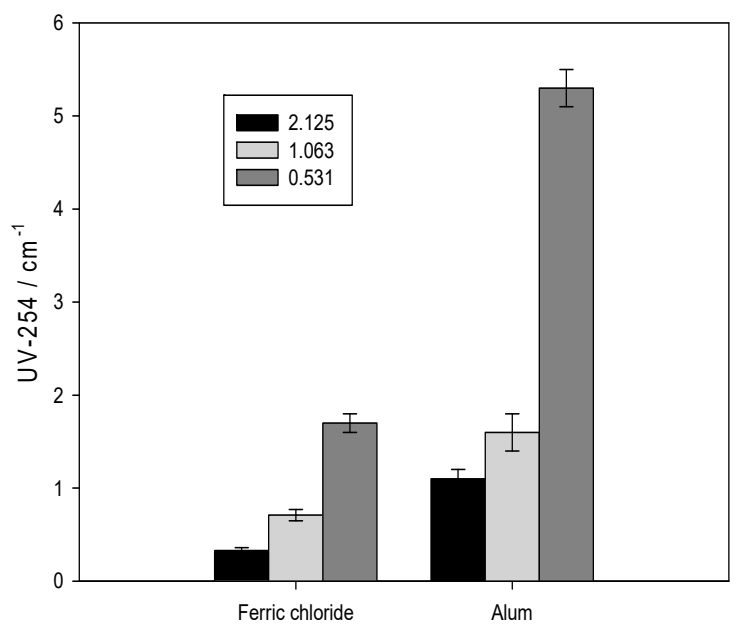

(c)

Figure 3. Differences between $\mathrm{FeCl}_{3}$ followed by homogeneous photo-Fenton and alum followed by ZVI heterogeneous photo-Fenton: (a) percentage of COD removal; (b) biodegradability enhancement through $\mathrm{BOD}_{5} / \mathrm{COD} ;$ (c) UV-254 absorbance. 
The second approach was the use of photofenton process after coagulation at $\mathrm{pH}=7$ with $5 \mathrm{~g} / \mathrm{L}$ of alum using ZVI as iron source. In this case, the UV irradiation time for complete $\mathrm{H}_{2} \mathrm{O}_{2}$ consumption was much longer than in ferric chloride case: 60, 120 and $150 \mathrm{~min}$ for the ratios of $\mathrm{H}_{2} \mathrm{O}_{2} / \mathrm{COD} 0.531$, 1.063 and 2.125, respectively (from 5 to 8 times higher than for ferric chloride). These differences in the irradiation time could be explained because of the lower UV-254 removal in the case of pre-coagulated leachate with alum than ferric chloride, probably by the lowest $\mathrm{pHs}$ after coagulation with ferric chloride compared to alum. Another reason explaining this difference is that the heterogeneous photo-Fenton at neutral $\mathrm{pHs}$ has slower kinetics [52]. Furthermore, the biodegradability increase was also much lower than in homogeneous photo-Fenton at acidic pHs, as occurred with COD. The $\mathrm{BOD}_{5} / \mathrm{COD}$ ratios after the treatment were $0.15,0.18$ and 0.25 , while the COD removals were $5 \%, 39 \%$ and $62 \%$, at increased $\mathrm{H}_{2} \mathrm{O}_{2} / \mathrm{COD}$ ratios. Additionally, alum removed $57 \%, 87 \%$ and $91 \%$ of UV-254 at increased $\mathrm{H}_{2} \mathrm{O}_{2} / \mathrm{COD}$ ratios. These removals are in the same range as ferric chloride, showing that UVQS have been almost totally removed for the two highest ratios $\mathrm{H}_{2} \mathrm{O}_{2} / C O D$, as shown in Figure 3.

For both approaches, the color removal was greater than $95 \%$ while the $\mathrm{pH}$ and the conductivity were not affected significantly by photo-Fenton treatment; the pH only decreased slightly as a consequence of hydrogen peroxide addition.

Table 4 summarizes the main obtained results. Fenton-like process using $\mathrm{Fe}^{3+}$ after $\mathrm{FeCl}_{3}$ coagulation obtained slightly greater COD removals than heterogeneous photo-Fenton after alum coagulation, but this last one requires less $\mathrm{pH}$ modification and salts addition. On the other hand, the Fenton-like process implies significantly lower UV irradiation time: 10-30 min for ferric chloride compared to $60-150$ min with alum, depending on the ratio $\mathrm{H}_{2} \mathrm{O}_{2} / \mathrm{COD}$. Furthermore, photo-oxidation of $\mathrm{FeCl}_{3}$ pre-coagulated waters had greater biodegradabilities (0.25-0.51 vs. 0.15-0.25) at the $\mathrm{H}_{2} \mathrm{O}_{2} / \mathrm{COD}$ ratios of $0.531,1.063$ and 2.125 , which makes possible a post-treatment by a conventional biological treatment to achieve the discharge limits established by legislation.

Table 4. Main characteristics of the process.

\begin{tabular}{|c|c|c|c|c|c|c|}
\hline & \multicolumn{3}{|c|}{$\begin{array}{l}\text { Ferric Chloride }+ \text { Homogeneous } \\
\text { Photo-Fenton (Acidic pH) }\end{array}$} & \multicolumn{3}{|c|}{$\begin{array}{l}\text { Alum + Heterogeneous ZVI } \\
\text { Photo-Fenton (Neutral pH) }\end{array}$} \\
\hline Initial pH (before coagulation) & \multicolumn{3}{|c|}{5.0} & \multicolumn{3}{|c|}{7.0} \\
\hline$\left[\mathrm{H}_{2} \mathrm{SO}_{4}\right], \mathrm{g} / \mathrm{L}$ & \multicolumn{3}{|c|}{7.2} & \multicolumn{3}{|c|}{1.0} \\
\hline [Coagulant], g/L & \multicolumn{3}{|c|}{2.0} & \multicolumn{3}{|c|}{5.0} \\
\hline $\begin{array}{l}\mathrm{COD} \text { after coagulation, } \mathrm{mg} \mathrm{O}_{2} / \mathrm{L} \\
(\% \text { removal })\end{array}$ & \multicolumn{3}{|c|}{$1588 \pm 226(68 \%)$} & \multicolumn{3}{|c|}{$1786 \pm 232(64 \%)$} \\
\hline $\mathrm{H}_{2} \mathrm{O}_{2} / \mathrm{COD}$ ratio & 2.125 & 1.063 & 0.531 & 2.125 & 1.063 & 0.531 \\
\hline Final $\mathrm{pH}$ after coagulation & $2.8 \pm 0.1$ & $2.8 \pm 0.1$ & $2.8 \pm 0.1$ & $6.7 \pm 0.1$ & $6.7 \pm 0.1$ & $6.7 \pm 0.1$ \\
\hline Conductivity, mS/cm & $22.5 \pm 0.2$ & $22.5 \pm 0.2$ & $22.5 \pm 0.2$ & $17.1 \pm 0.2$ & $17.1 \pm 0.2$ & $17.1 \pm 0.2$ \\
\hline UV irradiation time, min & 30 & 15 & 10 & 150 & 120 & 60 \\
\hline$\%$ COD removal (after oxidation) & $70 \%$ & $48 \%$ & $24 \%$ & $62 \%$ & $39 \%$ & $5 \%$ \\
\hline Final COD, $\mathrm{mg} \mathrm{O}_{2} / \mathrm{L}$ & $476 \pm 5$ & $826 \pm 8$ & $1207 \pm 12$ & $679 \pm 7$ & $1089 \pm 11$ & $1697 \pm 17$ \\
\hline $\mathrm{BOD}_{5} / \mathrm{COD}$ & 0.51 & 0.32 & 0.25 & 0.25 & 0.18 & 0.15 \\
\hline
\end{tabular}

After the proposed treatments, a high removal of contaminants together with an important increase in biodegradability have been obtained. At the best cases, accumulated contaminants removal were: $85-90 \%$ for COD; $90-95 \%$ for UV-254; and $>99 \%$ color; together with a high removal of heavy metals, i.e., $75 \%$ total $\mathrm{Cr}$ and $90 \% \mathrm{Ba}$. However, these removals are not high enough to achieve the discharge limits established in the Directive 91/271/EEC on urban wastewater treatment: $125 \mathrm{ppm}$ COD, 25 ppm BOD $5,60 \mathrm{mg} / \mathrm{L}$ TSS, $2 \mathrm{mg} / \mathrm{L}$ total $\mathrm{P}$ and $15 \mathrm{mg} / \mathrm{L}$ total $\mathrm{N}$. While the removals of TSS and 
TP were high enough to achieve the discharge limits after the proposed treatments (TSS $<25 \mathrm{mg} / \mathrm{L}$ and $\mathrm{TP}<1.5 \mathrm{mg} / \mathrm{L} \mathrm{P})$, this is not the case for COD (480-680 ppm), BOD 5 (170-240 ppm) and TN, which was only removed by $20 \%$ by these treatments $(\mathrm{TN}=1250 \mathrm{mg} \mathrm{N} / \mathrm{L}$ ). Therefore, after the proposed treatments, there will be necessary a biological treatment with simultaneous removal of $\mathrm{BOD}_{5}$ and nutrients (nitrogen). Among biological methods, sequencing batch reactor (SBR) would be the recommend treatment due to its high performance in treating landfill leachates, achieving high COD removals $\left(>75 \%\right.$ ) and almost total removal of ammonia-nitrogen (up to $99 \%$ ) even at intermediate BOD $_{5} / \mathrm{COD}$ ratio [53]. Before this biological treatment, a neutralization step will be necessary only in the case of the LL treated in homogeneous photo-Fenton $(\mathrm{pH} \approx 2.5)$.

The increase in biodegradabilities obtained after photo-Fenton treatments can be considered sufficient for biological treatment, especially in the case of LL leachate treated by ferric chloride. Although the ratio $\mathrm{BOD}_{5} / \mathrm{COD}=0.4$ is usually considered necessary for an efficient post-treatment of a mature LL treated by AOPs [54,55], there are also studies demonstrating high COD and TN removals can be obtained even at $\mathrm{BOD}_{5} / \mathrm{COD} \approx 0.2$. $\mathrm{H}$. Li et al. (2009) [56], for example, treated a mature LL by SBR with an initial $\mathrm{BOD}_{5} / \mathrm{COD}$ ratio of 0.22 (3000 ppm COD and $650 \mathrm{ppm} \mathrm{BOD}_{5}$ ), obtaining $79 \%$ removal of COD and $95 \% \mathrm{DBO}_{5}$. Furthermore, ammonia was totally removed, from $1100 \mathrm{mg} / \mathrm{L}$ to $<3 \mathrm{mg} / \mathrm{L}$. Similarly, B. Xie et al. (2010) [57], treated a mature LL by a biofilter packed with slag after a biofilter packed with aged refuse and Fenton oxidation. Even the ratio $\mathrm{BOD}_{5} / \mathrm{COD}$ was 0.20 before the biofilter, pilot scale tests demonstrated this treatment was capable of decreasing COD from $230 \mathrm{mg} / \mathrm{L}$ to $86 \mathrm{mg} / \mathrm{L}$ (63\% removal) and BOD from $44 \mathrm{mg} / \mathrm{L}$ to $9 \mathrm{mg} / \mathrm{L}$ (79\% removal). Furthermore, ammonium was removed from $212 \mathrm{mg} / \mathrm{L} \mathrm{N}$ to $20 \mathrm{mg} / \mathrm{L} \mathrm{N}$ (91\% removal). This means both proposed treatments could be further treated in a biological treatment to achieve discharge limits. In the case of the LL treated with ferric chloride and homogenous photo-Fenton, it would be possible also to work at intermediate $\mathrm{H}_{2} \mathrm{O}_{2} / \mathrm{COD}$ ratio (1.063), thus reducing the amount of chemicals used. When using AOPs, the optimal treatment consist on increasing the biodegradability of the wastewater using the lowest amount of chemicals possible, avoiding the need to use greater amounts only to reduce the COD, which can be more economically removed in conventional biological treatments [39].

\subsection{Economic Assesment}

An economic comparison of the two studied approaches has been performed (Table 5). The comparison is made with the data obtained at laboratory scale and only includes the main operational cost, i.e., chemicals consumption and energy costs. Management of the sludge generated after coagulation, for example, has not been considered. To obtain more reliable estimations in energy costs, the power consumption obtained at lab scale were decreased taking into account that the UV lamp used in the experiments has 15-18\% efficiency in UV radiation compared to power consumption (data given by the supplier), while modern UV lamps, available in the market, offer around $40 \%$ UV radiation efficiencies. Although it is expected that at industrial scale the cost will be reduced, this approach allows a rough comparison between the two studied approaches [52]. The cost of ferric chloride ( $200 € /$ ton, $40 \mathrm{wt} \%$ ), alum (180€/ton, pure), hydrogen peroxide (35 wt\%) (350€/ton), concentrated sulphuric acid (130 €/ton) are average values obtained from alibaba.com (industrial grade). The cost of the power is calculated using the average cost of electricity in Spain $(0.11 € / \mathrm{kWh})$.

The approach using acidic conditions is clearly more economic than the approach at neutral $\mathrm{pH}$, the estimated cost being 4 times lower $\left(6.44 € / \mathrm{m}^{3}\right.$ vs. $\left.28.44 € / \mathrm{m}^{3}\right)$. Although the approach at neutral $\mathrm{pH}$ with alum decreased the costs of the coagulation treatment (sulphuric acid for $\mathrm{pH}$ regulation and coagulant costs), would benefit from a lower amount of sludge generated and would avoid a further neutralization step before a final biological treatment to achieve discharge limits, this approach cannot be considered as a real alternative to coagulation with ferric chloride and homogenous photo-Fenton. The most important cost of these treatments, i.e., the power consumption by UV lamp, was around 8 times higher in heterogeneous Fenton compared to homogeneous Fenton due to the longer UV radiation time required (120 $\mathrm{min}$ vs. $15 \mathrm{~min}$ ). 
Table 5. Estimation of treatment costs by coagulation at optimal conditions and Fenton process using $\mathrm{H}_{2} \mathrm{O}_{2} / \mathrm{COD}=1.063$.

\begin{tabular}{ccc}
\hline Treatment Costs & $\mathbf{F e C l}_{3}$ & Alum \\
\hline Sulphuric acid $/ € / \mathrm{m}^{3}$ & 0.94 & 0.13 \\
Coagulant $/ € / \mathrm{m}^{3}$ & 1.00 & 0.90 \\
Hydrogen peroxide $/ € / \mathrm{m}^{3}$ & 1.18 & 1.33 \\
Power consumption $/ € / \mathrm{m}^{3}$ & 3.32 & 26.08 \\
\hline Total cost $/ € / \mathrm{m}^{3}$ & 6.44 & 28.44 \\
Photo-Fenton $/ € / \mathrm{kg} \mathrm{COD} \mathrm{removed}$ & 8.45 & 40.80 \\
\hline Coagulation + Photo-Fenton $/ € / \mathrm{kg}$ COD removed & 1.56 & 7.34 \\
\hline
\end{tabular}

The estimated costs for the treatment based on ferric chloride and homogenous photo-Fenton can be considered competitive. They are even better than results reported by several authors for the treatment of mature LL by AOPs, despite the cost of the final biological stage was not considered. For example, A. Anfruns et al. (2013) [58] estimated the associated costs for the treatment of a mature LL with $\mathrm{BOD}_{5} / \mathrm{COD}=0.13$, similar COD to that of the present study $(6200 \mathrm{mg} / \mathrm{L})$ and slightly higher total nitrogen $(2309 \mathrm{mg} / \mathrm{L})$ by the combination of a biological method (anammox) with two AOP: coagulation with ferric chloride plus ozonization, and homogenous photo-Fenton. In both cases, the estimated costs were in the $7-8 € / \mathrm{m}^{3}$ range, compared to the $6.5 € / \mathrm{m}^{3}$ obtained in the present study. C. Tizaouoi et al. (2007) [23] also estimated the cost for the treatment of a mature LL of similar characteristics to that of the studied LL (ratio $\mathrm{BOD}_{5} / \mathrm{COD}=0.10$ and $5230 \mathrm{mg} / \mathrm{L} \mathrm{COD}$,) by a combination of ozone and hydrogen peroxide. The associated costs to remove $52 \%$ COD were estimated to be around $2.3 \$ / \mathrm{kg}$ COD removed (6.3\$ $\$ \mathrm{~m}^{3}$ in that case), similar to the results obtained in the present study. S. Cortez et al. $(2010,2011)[55,59]$ treated a mature $\mathrm{LL}$ of $\mathrm{BOD}_{5} / \mathrm{COD}=0.01$ by different AOPs and obtained the following treatment costs: $8.2 € / \mathrm{kg}$ COD removed in homogenous Fenton, $38-64 € / \mathrm{kg}$ COD removed for ozonization at different initial $\mathrm{pHs}$ and $25-32 € / \mathrm{kg}$ COD removed by the combination of ozonization and hydrogen peroxide. These high costs are related to the low initial COD content in the tests (around $340 \mathrm{ppm}$ ) which is a consequence of a low initial COD content of the LL (around $743 \mathrm{ppm}$ ) and the 1:3 dilution used in the tests. Similarly, F.J. Rivas (2003) [60] made a rough operational costs estimation for homogenous the Fenton treatment of a mature LL, obtaining a value of $8 \$ / \mathrm{kg}$ COD removed, $\mathrm{H}_{2} \mathrm{O}_{2}$ consumption representing $75 \%$ of total operating costs. Although the initial COD was not low ( $2100 \mathrm{mg} / \mathrm{L}$ ), high $\mathrm{H}_{2} \mathrm{O}_{2}$ consumptions were observed: around $10 \mathrm{mg}$ of $\mathrm{H}_{2} \mathrm{O}_{2}$ per $\mathrm{mg}$ of COD, thus increasing the costs significantly. On the other hand, Torres-Socías et al. (2015) [61] reported about $40 € / \mathrm{m}^{3}$ for the treatment of a LL using compound parabolic collector (CPC) solar photoreactors, although they treated a higher load of COD. In addition, Silva et al. (2016) [62] compared the treatment of LL by the photo-Fenton process using UV lamps and solar radiation, reporting similar values for the different sources of radiation. For example, $11.0 € / \mathrm{m}^{3}$ were addressed to achieve $150 \mathrm{ppm}$ of COD just using the CPCs, whereas $11.7 € / \mathrm{m}^{3}$ corresponded to using UV lamps, and $10.9 € / \mathrm{m}^{3}$ combining CPCs and UV lamps. The values were just about $6-7 € / \mathrm{m}^{3}$ when the objective was a final COD value lower that $1000 \mathrm{ppm}$. Unfortunately, from 3836 to $6850 \mathrm{~m}^{2}$ of CPCs were necessary to perform such solar treatment [61,62], therefore implying the need of a large space, about $11,000-18,000 \mathrm{~m}^{2}$. In this studied case, around $2000 \mathrm{~m}^{2}$ of CPCs and $5500 \mathrm{~m}^{2}$ of surface area would be necessary. Furthermore, and advantageously, the iron source came from the previous coagulation process in this case, avoiding the need to use external iron sources, which are mainly based on the use of ferrous sulfate [62], and will increase the cost and complicate the management of the produced iron sludge.

The estimated treatment costs, even if the final biological treatment necessary to achieve the discharge limits is not considered, are within the estimated range for real installations. References discussing associated costs for on-site treatment of LL have given the following cost ranges: 4.5-12 $\$ / \mathrm{m}^{3}$ [63], 8-20 $€ / \mathrm{m}^{3}[64]$ and $1-23 € / \mathrm{m}^{3}$ [65], depending on the complexity of the treatment. 
The very low $\mathrm{BOD}_{5} / \mathrm{COD}$ ratio and the high COD of the LL treated in this study would need of a complex treatment with associated costs in the upper part of the presented rages.

However, leachate treatment costs can vary significantly depending on leachate type and site-specific conditions including age of landfill, strength of leachate, volume of leachate produced, standard of construction, rainfall intensity, availability of appropriate receiving waters and proximity to a wastewater treatment plant [65]. At present, the studied LL is treated in a publicly operated wastewater treatment plant located at less than $5 \mathrm{~km}$ from the landfill. The proximity to the wastewater treatment plant and the fact that this wastewater treatment plant can accept landfill leachates at reduced fees are strong arguments for using this off-site treatment. The treatment presented in this study could hardly compete with the current treatment as the associated costs are reduced while, at the same time, the need for new investments is avoided.

This does not mean the treatment could be competitive for similar LL in other conditions. Co-treatment in urban wastewater treatment usually has high costs, typically in the $25-30 € / \mathrm{m}^{3}$ range, roughly distributed in 50\% transport (estimated at an average $70 \mathrm{~km}$ distance from landfill to wastewater plant) and $50 \%$ gate fees $[65,66]$. Furthermore, increasingly, wastewater treatment plants (WWTPs) emission limits will continue to threaten the sustainability of co-treatment of leachate with municipal wastewater. The seasonal variation in leachate production also poses a risk to effective co-treatment in municipal WWTPs, as periods of high leachate production coincide with periods of maximum hydraulic loading in WWTPs [66]. The introduction of a $\mathrm{NH}_{4}-\mathrm{N}$ loading-based tariff at WWTPs would have a significant impact on the economics of on-site LL treatment as this would provide landfill managers with a business case to invest in on-site treatment of leachate [65]. The usually higher associated costs as well as these difficulties are the reasons why the number of landfills co-treating their LL in WWTPs are decreasing, while the number of landfills using advanced on-site treatments is increasing.

\section{Conclusions}

The results show that similar COD removal $(>65 \%)$ and color removal $(>90 \%)$ can be obtained with alum and ferric chloride coagulation at optimal conditions, contrary to the results from previous publications treating LL. Coagulation with alum presents some advantages with respect to ferric chloride such as the lower amount of sulphuric acid required for $\mathrm{pH}$ regulation $(1.0 \mathrm{~g} / \mathrm{L}$ for alum and $7.2 \mathrm{~g} / \mathrm{L}$ for ferric chloride), a $25 \%$ lower sludge production, the lower conductivity of the treated LL (17.1 vs. $22.5 \mathrm{mS} / \mathrm{cm}$ ) as well as a slightly lower cost. This justifies its combination with ZVI in heterogeneous photo-Fenton treatment to increase biodegradability at neutral $\mathrm{pH}$. However, although COD was successfully removed in photo-Fenton at neutral $\mathrm{pH}$, the final costs of the treatment was around 4 times more expensive $\left(28.4 € / \mathrm{m}^{3}\right.$ vs. $\left.6.4 € / \mathrm{m}^{3}\right)$ than coagulation with ferric chloride at acid conditions and homogeneous photo-Fenton due to the high energy consumption by the UV lamp. At the highest $\mathrm{H}_{2} \mathrm{O}_{2} / \mathrm{COD}$ ratio tested (2.125), heterogeneous ZVI photo-Fenton needed $150 \mathrm{~min}$ to increase the leachate biodegradability up to 0.32 while, homogeneous photo Fenton only needed 30 min to achieve a value of 0.51 . Besides the slower kinetics of the heterogeneous vs. homogenous photo-Fenton, this can be also explained by the lower UV-254 removal in coagulation with alum compared to ferric chloride ( $55 \%$ vs. $83 \%$ ) due to the null precipitation of humic acids at neutral $\mathrm{pH}$. After the proposed treatments, a final biological treatment, i.e., SBR, would be necessary to achieve the discharge limits, especially in terms of $\mathrm{COD}, \mathrm{BOD}_{5}$ and total nitrogen. Although the highest biodegradabilities obtained in homogeneous Fenton would be beneficial, previous studies demonstrate that mature LL can be efficiently treated even at $\mathrm{DBO}_{5} / \mathrm{COD} \approx 0.2$, which allows reducing the consumption of $\mathrm{H}_{2} \mathrm{O}_{2}$ in homogeneous photo-Fenton treatment to $\mathrm{H}_{2} \mathrm{O}_{2} / \mathrm{COD}=1.063$. The estimated treatment costs for the combination of treatments can be considered competitive compared to values from real installations in the published data. However, the reduced costs of the presently used off-site treatment of this LL limits the application of the studied treatments in this landfill. 
Author Contributions: Conceptualization, J.T., R.M., D.H., C.N. and Á.B.; Data curation, J.T., R.M. and D.H.; Formal analysis, J.T., R.M. and I.U.; Funding acquisition, C.N. and Á.B.; Investigation, J.T., R.M., D.H. and I.U.; Methodology, J.T., R.M., D.H., I.U., C.N. and Á.B.; Supervision, C.N. and Á.B.; Writing-original draft, J.T.; Writing-review and editing, J.T., R.M., D.H., C.N. and Á.B.

Funding: This research was funded by the Spanish Ministry of Economy, Industry and Competitiveness through the project "Tratamiento de concentrados: extendiendo los límites de la reutilización y el uso sostenible del agua en la industria" (CTM2016-77948-R).

Acknowledgments: The authors would like to thank Golmayo's Center of Waste Management (Soria, Spain) for kindly supplying the LL used in this study.

Conflicts of Interest: The authors declare no conflict of interest. The funders had no role in the design of the study; in the collection, analyses, or interpretation of data; in the writing of the manuscript; or in the decision to publish the results.

\section{References}

1. Lema, J.M.; Mendez, R.; Blazquez, R. Characteristics of landfill leachates and alternatives for their treatment: A review. Water Air Soil Pollut. 1988, 40, 223-250.

2. Bhagawan, D.; Poodari, S.; Chaitanya, N.; Ravi, S.; Rani, Y.M.; Himabindu, V.; Vidyavathi, S. Industrial solid waste landfill leachate treatment using electrocoagulation and biological methods. Desalin. Water Treat. 2017, 68, 137-142. [CrossRef]

3. Mukherjee, S.; Mukhopadhyay, S.; Hashim, M.A.; Sen Gupta, B. Contemporary Environmental Issues of Landfill Leachate: Assessment and Remedies. Crit. Rev. Environ. Sci. Technol. 2015, 45, 472-590. [CrossRef]

4. Abbas, A.A.; Jingsong, G.; Ping, L.Z.; Ya, P.Y.; Al-Rekabi, W.S. Review on LandWll Leachate Treatments. J. Appl. Sci. Res. 2009, 5, 534-545.

5. Justin, M.Z.; Zupančič, M. Combined purification and reuse of landfill leachate by constructed wetland and irrigation of grass and willows. Desalination 2009, 246, 157-168. [CrossRef]

6. Biglarijoo, N.; Mirbagheri, S.A.; Ehteshami, M.; Ghaznavi, S.M. Optimization of Fenton process using response surface methodology and analytic hierarchy process for landfill leachate treatment. Process Saf. Environ. Prot. 2016, 104, 150-160. [CrossRef]

7. Rodríguez, J.; Castrillón, L.; Marañón, E.; Sastre, H.; Fernández, E. Removal of non-biodegradable organic matter from landfill leachates by adsorption. Water Res. 2004, 38, 3297-3303. [CrossRef]

8. Nanny, M.A.; Ratasuk, N. Characterization and comparison of hydrophobic neutral and hydrophobic acid dissolved organic carbon isolated from three municipal landfill leachates. Water Res. 2002, 36, 1572-1584. [CrossRef]

9. Foo, K.; Hameed, B. An overview of landfill leachate treatment via activated carbon adsorption process. J. Hazard. Mater. 2009, 171, 54-60. [CrossRef]

10. Kjeldsen, P.; Barlaz, M.A.; Rooker, A.P.; Baun, A.; Ledin, A.; Christensen, T.H. Present and long-term composition of MSW landfill leachate: A review. Crit. Rev. Environ. Sci. Technol. 2002, 32, 297-336. [CrossRef]

11. Ahmed, F.N.; Lan, C.Q. Treatment of landfill leachate using membrane bioreactors: A review. Desalination 2012, 287, 41-54. [CrossRef]

12. Bove, D.; Merello, S.; Frumento, D.; Al Arni, S.; Aliakbarian, B.; Converti, A. A Critical Review of Biological Processes and Technologies for Landfill Leachate Treatment. Chem. Eng. Technol. 2015, 38, 2115-2126. [CrossRef]

13. Yalcuk, A.; Ugurlu, A. Comparison of horizontal and vertical constructed wetland systems for landfill leachate treatment. Bioresour. Technol. 2009, 100, 2521-2526. [CrossRef]

14. Torretta, V.; Ferronato, N.; Katsoyiannis, I.A.; Tolkou, A.K.; Airoldi, M. Novel and conventional technologies for landfill leachates treatment: A review. Sustainability 2016, 9, 9. [CrossRef]

15. Teh, C.Y.; Budiman, P.M.; Shak, K.P.Y.; Wu, T.Y. Recent Advancement of Coagulation-Flocculation and Its Application in Wastewater Treatment. Ind. Eng. Chem. Res. 2016, 55, 4363-4389. [CrossRef]

16. Latour, I.; Miranda, R.; Blanco, A. Silica removal from newsprint mill effluents with aluminum salts. Chem. Eng. J. 2013, 230, 522-531. [CrossRef]

17. Kurniawan, T.; Lo, W.; Chan, G.Y.S. Physico-chemical treatments for removal of recalcitrant contaminants from landfill leachate. J. Hazard. Mater. 2006, 129, 80-100. [CrossRef] 
18. Aziz, H.A.; Alias, S.; Adlan, M.N.; Faridah; Asaari, A.; Zahari, M.S. Colour removal from landfill leachate by coagulation and flocculation processes. Bioresour. Technol. 2007, 98, 218-220. [CrossRef]

19. Amor, C.; De Torres-Socías, E.; Peres, J.A.; Maldonado, M.I.; Oller, I.; Malato, S.; Lucas, M.S. Mature landfill leachate treatment by coagulation/flocculation combined with Fenton and solar photo-Fenton processes. J. Hazard. Mater. 2015, 286, 261-268. [CrossRef]

20. Silva, A.; Dezotti, M.; Sant'Anna, G., Jr. Treatment and detoxification of a sanitary landfill leachate. Chemosphere 2004, 55, 207-214. [CrossRef]

21. Hermosilla, D.; Merayo, N.; Ordóñez, R.; Blanco, A. Optimization of conventional Fenton and ultraviolet-assisted oxidation processes for the treatment of reverse osmosis retentate from a paper mill. Waste Manag. 2012, 32, 1236-1243. [CrossRef]

22. Wu, J.J.; Wu, C.-C.; Ma, H.-W.; Chang, C.-C. Treatment of landfill leachate by ozone-based advanced oxidation processes. Chemosphere 2004, 54, 997-1003. [CrossRef]

23. Tizaoui, C.; Bouselmi, L.; Mansouri, L.; Ghrabi, A.; Bousselmi, L. Landfill leachate treatment with ozone and ozone/hydrogen peroxide systems. J. Hazard. Mater. 2007, 140, 316-324. [CrossRef]

24. Yang, Y.; Jin, X.; Pan, Y.; Zuo, X. Study on Treatment of Landfill Leachate by Electrochemical, Flocculation and Photocatalysis. In Proceedings of the IOP Conference Series: Earth and Environmental Science, Chongqing, China, 25-26 November 2017; IOP Publishing: Bristol, UK, 2018.

25. Jia, C.; Wang, Y.; Zhang, C.; Qin, Q. UV-TiO 2 photocatalytic degradation of landfill leachate. Water Air Soil Pollut. 2011, 217, 375-385. [CrossRef]

26. Anglada, A.; Urtiaga, A.; Ortiz, I. Pilot scale performance of the electro-oxidation of landfill leachate at boron-doped diamond anodes. Environ. Sci. Technol. 2009, 43, 2035-2040. [CrossRef]

27. Turro, E.; Giannis, A.; Cossu, R.; Gidarakos, E.; Mantzavinos, D.; Katsaounis, A. Electrochemical oxidation of stabilized landfill leachate on DSA electrodes. J. Hazard. Mater. 2011, 190, 460-465. [CrossRef]

28. Ertugay, N.; Kocakaplan, N.; Malkoc, E. Investigation of pH Effect with Fenton-Like Oxidation using ZVI in Treatment of the Landfill Leachate. Int. J. Min. Reclamat. Environ. 2017, 31, 404-411. [CrossRef]

29. Hermosilla, D.; Cortijo, M.; Huang, C.P. Optimizing the treatment of landfill leachate by conventional Fenton and photo-Fenton processes. Sci. Total Environ. 2009, 407, 3473-3481. [CrossRef]

30. Zhang, H.; Choi, H.J.; Huang, C.P. Treatment of landfill leachate by Fenton's reagent in a continuous stirred tank reactor. J. Hazard. Mater. 2006, 136, 618-623. [CrossRef]

31. Zhang, H.; Choi, H.J.; Huang, C.-P. Optimization of Fenton process for the treatment of landfill leachate. J. Hazard. Mater. 2005, 125, 166-174. [CrossRef]

32. Silva, T.F.; Vieira, E.; Lopes, A.R.; Nunes, O.C.; Fonseca, A.; Saraiva, I.; Boaventura, R.A.; Vilar, V.J.; Silva, T.V. How the performance of a biological pre-oxidation step can affect a downstream photo-Fenton process on the remediation of mature landfill leachates: Assessment of kinetic parameters and characterization of the bacterial communities. Sep. Purif. Technol. 2017, 175, 274-286. [CrossRef]

33. Umar, M.; Aziz, H.A.; Yusoff, M.S. Trends in the use of Fenton, electro-Fenton and photo-Fenton for the treatment of landfill leachate. Waste Manag. 2010, 30, 2113-2121. [CrossRef]

34. Barndõk, H.; Merayo, N.; Blanco, L.; Hermosilla, D.; Blanco, Á. Application of on-line FTIR methodology to study the mechanisms of heterogeneous advanced oxidation processes. Appl. Catal. B Environ. 2016, 185, 344-352. [CrossRef]

35. Özdemir, C.; Tezcan, H.; Sahinkaya, S.; Kalipci, E. Pretreatment of Olive Oil Mill Wastewater by Two Different Applications of Fenton Oxidation Processes. CLEAN-Soil Air Water 2010, 38, 1152-1158. [CrossRef]

36. Lee, S.D.; Mallampati, S.R.; Lee, B.H. Hybrid zero valent iron (ZVI)/ $\mathrm{H}_{2} \mathrm{O}_{2}$ oxidation process for landfill leachate treatment with novel nanosize metallic calcium/iron composite. J. Air Waste Manag. Assoc. 2017, 67, 475-487. [CrossRef]

37. Martins, R.C.; Lopes, D.V.; Quina, M.J.; Quinta-Ferreira, R.M. Treatment improvement of urban landfill leachates by Fenton-like process using ZVI. Chem. Eng. J. 2012, 192, 219-225. [CrossRef]

38. Bogacki, J.; Marcinowski, P.; El-Khozondar, B. Treatment of Landfill Leachates with Combined Acidification/Coagulation and The $\mathrm{Fe}^{0} / \mathrm{H}_{2} \mathrm{O}_{2}$ Process. Water 2019, 11, 194. [CrossRef]

39. Lopez, A.; Pagano, M.; Volpe, A.; Di Pinto, A.C. Fenton's pre-treatment of mature landfill leachate. Chemosphere 2004, 54, 1005-1010. [CrossRef]

40. Chow, C.W.; Van Leeuwen, J.A.; Fabris, R.; Drikas, M. Optimised coagulation using aluminium sulfate for the removal of dissolved organic carbon. Desalination 2009, 245, 120-134. [CrossRef] 
41. Liang, X.; Zhu, X.; Butler, E.C. Comparison of four advanced oxidation processes for the removal of naphthenic acids from model oil sands process water. J. Hazard. Mater. 2011, 190, 168-176. [CrossRef]

42. American Public Health Association; American Water Works Association; Water Pollution Control Federation; Water Environment Federation. Standard Methods for the Examination of Water and Wastewater; APHA: Washington, DC, USA, 2005.

43. Silva, J.O.; Silva, V.M.; Cardoso, V.L.; Machado, A.E.H.; Trovó, A.G. Treatment of Sanitary Landfill Leachate by Photo-Fenton Process: Effect of the Matrix Composition. J. Braz. Chem. Soc. 2016, 27, 2264-2272. [CrossRef]

44. Roudi, A.M.; Akhlaghi, E.; Chelliapan, S.; Kaboli, A.; Aslani, H.; Selvam, S.B. Treatment of Landfill Leachate via Advanced Oxidation Process (AOPs)—A Review. Res. J. Pharm. Biol. Chem. Sci. 2015, 6, 260-271.

45. Renou, S.; Givaudan, J.; Poulain, S.; Dirassouyan, F.; Moulin, P. Landfill leachate treatment: Review and opportunity. J. Hazard. Mater. 2008, 150, 468-493. [CrossRef]

46. Zhao, R.; Jung, C.; Trzopek, A.; Torrens, K.; Deng, Y. Characterization of ultraviolet-quenching dissolved organic matter (DOM) in mature and young leachates before and after biological pre-treatment. Environ. Sci. Water Res. Technol. 2018, 4, 731-738. [CrossRef]

47. Iskander, S.M.; Novak, J.T.; Brazil, B.; He, Z. Percarbonate oxidation of landfill leachates towards removal of ultraviolet quenchers. Environ. Sci. Water Res. Technol. 2017, 3, 1162-1170. [CrossRef]

48. Iskander, S.M.; Zhao, R.; Pathak, A.; Gupta, A.; Pruden, A.; Novak, J.T.; He, Z. A review of landfill leachate induced ultraviolet quenching substances: Sources, characteristics, and treatment. Water Res. 2018, 145, 297-311. [CrossRef]

49. Aguilar, M.I.; Saez, J.; Llorens, M.; Soler, A.; Ortuno, J.F. Nutrient removal and sludge production in the coagulation-flocculation process. Water Res. 2002, 36, 2910-2919. [CrossRef]

50. Assou, M.; Madinzi, A.; Anouzla, A.; Aboulhassan, M.A.; Souabi, S.; Hafidi, M. Reducing pollution of stabilized landfill leachate by mixing of coagulants and flocculants: A comparative study. Int. J. Eng. Innov. Technol. 2014, 4, 20-25.

51. Kochany, J.; Lipczynska-Kochany, E. Utilization of landfill leachate parameters for pretreatment by Fenton reaction and struvite precipitation-A comparative study. J. Hazard. Mater. 2009, 166, 248-254. [CrossRef]

52. Blanco, L.; Hermosilla, D.; Merayo, N.; Blanco, Á. Assessing the use of zero-valent iron microspheres to catalyze Fenton treatment processes. J. Taiwan Inst. Chem. Eng. 2016, 69, 54-60. [CrossRef]

53. Yong, Z.J.; Bashir, M.J.; Ng, C.A.; Sethupathi, S.; Lim, J.-W. A sequential treatment of intermediate tropical landfill leachate using a sequencing batch reactor (SBR) and coagulation. J. Environ. Manag. 2018, 205, $244-252$. [CrossRef]

54. De Morais, J.L.; Zamora, P.P. Use of advanced oxidation processes to improve the biodegradability of mature landfill leachates. J. Hazard. Mater. 2005, 123, 181-186. [CrossRef]

55. Cortez, S.; Teixeira, P.; Oliveira, R.; Mota, M. Evaluation of Fenton and ozone-based advanced oxidation processes as mature landfill leachate pre-treatments. J. Environ. Manag. 2011, 92, 749-755. [CrossRef]

56. Li, H.-S.; Zhou, S.-Q.; Sun, Y.-B.; Feng, P.; Li, J.-D. Advanced treatment of landfill leachate by a new combination process in a full-scale plant. J. Hazard. Mater. 2009, 172, 408-415. [CrossRef]

57. Xie, B.; Lv, Z.; Lv, B.; Gu, Y. Treatment of mature landfill leachate by biofilters and Fenton oxidation. Waste Manag. 2010, 30, 2108-2112. [CrossRef]

58. Anfruns, A.; Gabarró, J.; Olmos, R.G.; Puig, S.; Balaguer, M.D.; Colprim, J. Coupling anammox and advanced oxidation-based technologies for mature landfill leachate treatment. J. Hazard. Mater. 2013, 258, 27-34. [CrossRef]

59. Cortez, S.; Teixeira, P.; Oliveira, R.; Mota, M. Ozonation as polishing treatment of mature landfill leachate. J. Hazard. Mater. 2010, 182, 730-734. [CrossRef]

60. Rivas, F.J.; Beltran, F.; Gimeno, O.; Carvalho, F. Fenton-like oxidation of landfill leachate. J. Environ. Sci. Health Part A Environ. Sci. Eng. 2003, 38, 371-379. [CrossRef]

61. De Torres-Socías, E.; Prieto-Rodríguez, L.; Zapata, A.; Fernández-Calderero, I.; Oller, I.; Malato, S. Detailed treatment line for a specific landfill leachate remediation. Brief economic assessment. Chem. Eng. J. 2015, 261, 60-66. [CrossRef]

62. Silva, T.F.; Fonseca, A.; Saraiva, I.; Boaventura, R.A.; Vilar, V.J.; Silva, T.V. Scale-up and cost analysis of a photo-Fenton system for sanitary landfill leachate treatment. Chem. Eng. J. 2016, 283, 76-88. [CrossRef] 
63. Wu, L.N.; Liang, D.W.; Xu, Y.Y.; Liu, T.; Peng, Y.Z.; Zhang, J. A robust and cost-effective integrated process for nitrogen and bio-refractory organics removal from landfill leachate via short-cut nitrification, anaerobic ammonium oxidation in tandem with electrochemical oxidation. Bioresour. Technol. 2016, 212, 296-301. [CrossRef]

64. Climate and Clean Air Coalition. Municipal Solid Waste Initiative. Leachate Management Costs; Climate and Clean Air Coalition: Paris, France, 2013.

65. Brennan, R.B.; Healy, M.G.; Morrison, L.; Hynes, S.; Norton, D.; Clifford, E. Sustainability of Municipal Wastewater Treatment Plants for the Treatment of Landfill Leachate; Report No. 214. 2017; Environmental Protection Agency: Wexford, Ireland, 2017; ISBN 978-1-84095-711-2.

66. Brennan, R.B.; Healy, M.G.; Morrison, L.; Hynes, S.; Norton, D.; Clifford, E. Management of landfill leachate: The legacy of European Union Directives. Waste Manag. 2016, 55, 355-363. [CrossRef]

(C) 2019 by the authors. Licensee MDPI, Basel, Switzerland. This article is an open access article distributed under the terms and conditions of the Creative Commons Attribution (CC BY) license (http://creativecommons.org/licenses/by/4.0/). 